Research Article

\title{
Correlation and Path Coefficient Analysis of Yield and Yield Components of Quality Protein Maize (Zea mays L.) Hybrids at Jimma, Western Ethiopia
}

\author{
Jemal Aman $\mathbb{D}^{1},{ }^{1}$ Kassahun Bantte, ${ }^{2}$ Sentayehu Alamerew, ${ }^{2}$ and Desta Berhe Sbhatu $\mathbb{B}^{3}$ \\ ${ }^{1}$ Ethiopian Sugar Corporation Research and Training Division Variety Development Research Directorate Biotechnology \\ Research Team Wonji Research Center, Wonji, Ethiopia \\ ${ }^{2}$ College of Agriculture and Veterinary Medicine, Jimma University, Jimma, Ethiopia \\ ${ }^{3}$ Mekelle Institute of Technology, Mekelle University, P.O. Box 1632, Mekelle, Ethiopia \\ Correspondence should be addressed to Jemal Aman; jemalbeshir@gmail.com
}

Received 16 November 2019; Revised 16 March 2020; Accepted 25 March 2020; Published 8 June 2020

Academic Editor: Cristina Patanè

Copyright (C) 2020 Jemal Aman et al. This is an open access article distributed under the Creative Commons Attribution License, which permits unrestricted use, distribution, and reproduction in any medium, provided the original work is properly cited.

\begin{abstract}
Maize is one of the most important staple food crops in many parts of Ethiopia. However, it is not used extensively due to its poor nutritional quality and low productivity. It lacks two essential amino acids, namely, lysine and tryptophan. Knowledge of the interrelationships of grain yield and its various causal (contributory) components is very helpful to improve the efficiency of breeding programs using appropriate selection indices. This article reports the findings of a study conducted to determine the nature of relationships of grain yield and its contributing components and to identify those components with significant effects on yield with the intention of using them as selection criteria using path coefficient analysis (PCA). Therefore, PCA has shown that yield per hectare had a significant and positive phenotypic correlation with plant height, ear height, number of kernels per row, and 100-grain weight. Moreover, PCA had a significant and positive genotypic correlation with days to $50 \%$ tasseling, plant height, ear height, and 100-grain weight. The highest direct positive effect on yield per hectare was exhibited by ear height. The findings of this study showed that most genotypes are early maturing and are suitable for areas with short rainy seasons and prone to drought.
\end{abstract}

\section{Introduction}

Zea mays L. (Poaceae) is an important annual food crop of the world. It is the source of primary staple food as well as protein and calorie for millions of people in the world. Maize accounts for about 15 to $56 \%$ of the total daily calories in diets of people in several developing countries in Africa and Latin America, where animal protein is scarce and expensive [1]. It is produced for food among low-income families in Ethiopia and served in different dishes. Though several hundred million people depend on maize, its common (normal) variety lacks two essential amino acids, namely, lysine and tryptophan, which are required in the biosynthesis of proteins [2]. Therefore, the discovery of the recessive allele of the opaque- 2 maize gene was a significant breakthrough in the alleviation of global protein deficiency.
The high level of lysine and tryptophan amino acids in the maize endosperm protein is due to the presence of the recessive allele of the opaque- 2 gene in the genome of mutant maize [3]. This has created tremendous interest and enthusiasm in the scientific community for its potential in developing maize with superior protein quality. However, the gene was found to be closely associated with several undesirable traits. The opaque- 2 maize kernels were dull and chalky, had 15 to $20 \%$ less grain weight, and were more susceptible to several diseases and insects [4], which led to the loss of interest among scientists to work on it. After several trials and systematic studies, breeders succeeded in finding modifier genes that produce the desirable hard endosperm phenotype in materials containing the recessive opaque- 2 mutation. These agronomically acceptable and nutritionally enhanced materials later came to be known as 
quality protein maize (QPM) [2, 5-7]. QPM contains nearly twice as much usable protein as other maize varieties grown in the tropics and yields 10\% more grain than traditional maize varieties [2].

The principal goal of maize breeding programs is to develop new inbred and hybrid varieties that outperform the existing varieties with respect to many traits. In this pursuit, special attention is given to grain yield as the most important agronomic characteristic. Grain yield is a complex quantitative trait affected by a number of factors. Thus, the knowledge of interrelationships between grain yield and its contributing components improves the efficiency of breeding programs through the use of appropriate selection indices $[8,9]$. Path coefficient analysis has been widely used in crop breeding programs to determine the nature of relationships between grain yield and its contributing components and to identify the components with significant effects on yield to be used as selection criteria. Path analysis shows the direct and indirect effects of cause variables on effect variables [10-12]. According to this method, the correlation coefficient between two traits is separated into the components that measure the direct and indirect effects. This article reports the findings of a study that aimed at looking into the phenotypic and genotypic correlations between grain yield and other morphological traits and evaluating the direct and indirect effects of morphological traits on grain yield.

\section{Materials and Methods}

2.1. Description of the Study Area. The study was conducted between July and October 2009 at the Eladalle research station of the Jimma University College of Agriculture and Veterinary Medicine (alt.: $1722 \mathrm{~m}$; lat.: $7^{\circ} 33^{\prime \prime} 0^{\prime} \mathrm{N}$; and long.: $36^{\circ} 57^{\prime \prime} 0^{\prime} \mathrm{E}$ ). The mean maximum and minimum annual temperatures of the Eladalle research station are $26.8^{\circ} \mathrm{C}$ and $11.4^{\circ} \mathrm{C}$, respectively. Likewise, the mean maximum and the minimum annual relative humidity $(\mathrm{RH})$ of the station are $91.4 \%$ and $39.92 \%$, respectively. It also has a mean annual rainfall of $951.5 \mathrm{~mm}$. Its soil is reddish-brown clay soil with $\mathrm{pH}$ ranging from 5.07 to 6.0 [13].

2.2. Experimental Materials. The quality protein maize (QPM) hybrids used in this study were acquired from CIMMYT. The hybrids include 43 three-way hybrids and two checks (one commercial and another local). Details of materials are shown in Table 1.

2.3. Experimental Designs and Procedure. The materials were sown in the alpha lattice $(5 \times 9)$ with 5 plots per block with two replications in a 5 meters single row plot with the spacing of 0.75 meters between rows and 0.30 meters between plants. It may be argued that the number of replications is small. However, the efficiency of alpha-lattice design increases the precision of the experiment. All agronomic practices including land preparation, weeding, and fertilization were applied to all plots as per the standard practices for maize.
TABLE 1: List of QPM hybrids used in the study.

\begin{tabular}{|c|c|c|}
\hline Entry & Name & Origin \\
\hline 1 & CKH-08001 & KB08B-0B20-1/2 \\
\hline 2 & CKH-08002 & KB08B-0B20-21/22 \\
\hline 3 & CKH-08003 & KB08B-0B20-23/24 \\
\hline 4 & CKH-08004 & KB08B-0B20-27/28 \\
\hline 5 & СKH-08005 & KB08B-0B20-31/32 \\
\hline 6 & CKH-08006 & KB08B-0B20-33/34 \\
\hline 7 & CKH-08007 & KB08B-0B20-35/36 \\
\hline 8 & CKH-08008 & KB08B-0B20-39/40 \\
\hline 9 & СКH-08009 & KB08B-0B20-41/42 \\
\hline 10 & CKH-08010 & KB08B-0B20-45/46 \\
\hline 11 & CKH-08011 & KB08B-0B20-47/48 \\
\hline 12 & CKH-08012 & KB08B-0B20-49/50 \\
\hline 13 & СКH-08013 & KB08B-0B20-51/52 \\
\hline 14 & CKH-08014 & KB08B-0B20-55/56 \\
\hline 15 & CKH-08015 & KB08B-0B20-59/60 \\
\hline 16 & CKH-08016 & KB08B-0B20-61/62 \\
\hline 17 & CKH-08017 & KB08A-0A51-1/2 \\
\hline 18 & CKH-08018 & KB08A-0A51-3/4 \\
\hline 19 & CKH-08019 & KB08A-0A51-5/6 \\
\hline 20 & CKH-08020 & KB08A-0A51-9/10 \\
\hline 21 & CKH-08021 & KB08A-0A51-13/14 \\
\hline 22 & СКH-08022 & KB08A-0A51-15/16 \\
\hline 23 & CKH-08023 & KB08A-0A51-17/18 \\
\hline 24 & CKH-08024 & KB08A-0A51-19/20 \\
\hline 25 & CKH-08025 & KB08A-0A51-21/22 \\
\hline 26 & CKH-08026 & KB08A-0A51-29/30 \\
\hline 27 & CKH-08027 & KB08A-0A51-31/32 \\
\hline 28 & CKH-08028 & KB08A-0A51-35/36 \\
\hline 29 & CKH-08029 & KB08A-0A51-37/38 \\
\hline 30 & CKH-08030 & KB08A-0A51-43/44 \\
\hline 31 & CKH-08031 & KB08A-0A51-51/52 \\
\hline 32 & CKH-08032 & KB08A-0A51-53/54 \\
\hline 33 & CKH-08033 & KB08A-0A49-9/10 \\
\hline 34 & CKH-08034 & KB08A-0A49-17/18 \\
\hline 35 & CKH-08035 & KB08A-0A49-21/22 \\
\hline 36 & CKH-08036 & KB08A-0A49-23/24 \\
\hline 37 & CKH-08037 & KB08A-0A49-25/26 \\
\hline 38 & CKH-08038 & KB08A-0A49-41/42 \\
\hline 39 & СКH-08039 & KB08A-0A49-43/44 \\
\hline 40 & CKH-08040 & KB08A-0A49-27/28 \\
\hline 41 & QPMHYB1 & KB07B-0B37-1/2 \\
\hline 42 & QPMHYB2 & KB07B-0B35-1/2 \\
\hline 43 & QPMHYB3 & KB08B-0B20-71/71 \\
\hline 44 & WH403 & WS \\
\hline 45 & BH-660 & - \\
\hline
\end{tabular}

2.4. Data Sources and Analyses. Data for days to $50 \%$ tasseling, plant count, and grain yield of the hybrids were collected based on the whole plot. Likewise, data for plant height, ear height, number of kernel-rows per ear, and number of kernels per row were taken based on five randomly selected plants. Finally, 100-kernel weight was taken from composite seeds of all the plants from the plots after removing the plants at the ends of the rows. Their mean performances are given in Table 2. Phenotypic and genotypic correlations and path coefficient analysis were analyzed using GENRES Version 7.01. Phenotypic correlation (the observable correlation between two variables that include genotypic and environmental components) and genotypic correlation were computed using GENRES using the method described in Singh and Chaudhry [14] as 
TABLE 2: Mean performance of QPM hybrids evaluated at the College of Agriculture and Veterinary Medicine (Jimma University, Ethiopia) for different characters.

\begin{tabular}{|c|c|c|c|c|c|c|c|c|c|}
\hline Entry & Name & TS & $\mathrm{PH}$ & $\mathrm{EH}$ & $\mathrm{PC}$ & NRE & NKR & HGWt & Yield \\
\hline 1 & CKH-08001 & $82.00^{\mathrm{ba}}$ & 156.80 & $58.40^{1}$ & $14.50^{\mathrm{cb}}$ & 14.00 & 29.80 & 24.05 & $20.80^{\mathrm{h}}$ \\
\hline 2 & CKH-08002 & $79.00^{\mathrm{b}-\mathrm{g}}$ & 173.90 & $84.80^{\mathrm{b}-\mathrm{k}}$ & $12.00^{\mathrm{b}-\mathrm{e}}$ & 13.00 & 31.30 & 27.15 & $33.88^{\mathrm{c}-\mathrm{h}}$ \\
\hline 3 & CKH-08003 & $77.50^{\mathrm{b}-\mathrm{g}}$ & 174.20 & $68.00^{\mathrm{ij}}$ & $12.50^{\mathrm{b}-\mathrm{e}}$ & 14.00 & 30.30 & 22.00 & $26.03^{f-h}$ \\
\hline 4 & CKH-08004 & $80.50^{\mathrm{b}-\mathrm{d}}$ & 181.80 & $79.80^{\mathrm{c}-\mathrm{k}}$ & $14.00^{\mathrm{b}-\mathrm{d}}$ & 14.80 & 27.90 & 27.25 & $27.03^{\mathrm{f}-\mathrm{h}}$ \\
\hline 5 & CKH-08005 & $75.50^{\mathrm{c}-\mathrm{h}}$ & 198.10 & $91.28^{\mathrm{b}-\mathrm{g}}$ & $15.00^{\mathrm{b}}$ & 14.20 & 35.30 & 26.50 & $49.95^{\mathrm{b}-\mathrm{e}}$ \\
\hline 6 & CKH-08006 & $74.50^{\mathrm{f}-\mathrm{i}}$ & 206.30 & $93.80^{\mathrm{b}-\mathrm{f}}$ & $14.00^{\mathrm{b}-\mathrm{d}}$ & 13.40 & 32.20 & 28.80 & $35.00^{\mathrm{c}-\mathrm{h}}$ \\
\hline 7 & CKH-08007 & $73.50^{\mathrm{g}-\mathrm{i}}$ & 204.00 & $96.80^{\mathrm{b}-\mathrm{d}}$ & $14.00^{\mathrm{b}-\mathrm{d}}$ & 16.80 & 33.60 & 22.85 & $37.12^{\mathrm{c}-\mathrm{h}}$ \\
\hline 8 & CKH-08008 & $78.50^{\mathrm{b}-\mathrm{g}}$ & 188.10 & $80.50^{\mathrm{c}-\mathrm{k}}$ & $15.00^{\mathrm{b}}$ & 14.80 & 34.10 & 28.25 & $32.39^{\mathrm{c}-\mathrm{h}}$ \\
\hline 9 & CKH-08009 & $76.50^{\mathrm{b}-\mathrm{h}}$ & 185.50 & $88.40^{\mathrm{b}-\mathrm{i}}$ & $12.50^{\mathrm{b}-\mathrm{e}}$ & 14.60 & 33.60 & 26.65 & $39.86^{\mathrm{c}-\mathrm{h}}$ \\
\hline 10 & СКH-08010 & $79.00^{\mathrm{b}-\mathrm{g}}$ & 176.10 & $68.10^{\mathrm{ij}}$ & $13.00^{\mathrm{b}-\mathrm{e}}$ & 14.25 & 35.25 & 33.95 & $30.15^{\mathrm{e}-\mathrm{h}}$ \\
\hline 11 & CKH-08011 & $78.50^{\mathrm{b}-\mathrm{g}}$ & 170.80 & $70.20^{\mathrm{g}-\mathrm{j}}$ & $12.00^{\mathrm{b}-\mathrm{e}}$ & 14.20 & 34.50 & 27.25 & $27.16^{\mathrm{f}-\mathrm{h}}$ \\
\hline 12 & CKH-08012 & $77.50^{\mathrm{b}-\mathrm{g}}$ & 192.80 & $87.30^{\mathrm{b}-\mathrm{i}}$ & $12.50^{\mathrm{b}-\mathrm{e}}$ & 14.60 & 36.50 & 29.05 & $39.36^{c-h}$ \\
\hline 13 & СКH-08013 & $76.00^{\mathrm{c}-\mathrm{h}}$ & 188.70 & $77.50^{\mathrm{d}-\mathrm{j}}$ & $14.50^{\mathrm{bc}}$ & 13.60 & 34.30 & 29.55 & $34.13^{\mathrm{c}-\mathrm{h}}$ \\
\hline 14 & CKH-08014 & $78.50^{\mathrm{b}-\mathrm{g}}$ & 187.90 & $84.80^{\mathrm{b}-\mathrm{i}}$ & $13.00^{\mathrm{b}-\mathrm{e}}$ & 14.80 & 30.30 & 22.00 & $24.17^{\text {gh }}$ \\
\hline 15 & СКН-08015 & $77.00^{\mathrm{b}-\mathrm{g}}$ & 199.30 & $88.20^{\mathrm{b}-\mathrm{i}}$ & $13.00^{\mathrm{b}-\mathrm{i}}$ & 14.20 & 34.20 & 28.20 & $35.12^{\mathrm{c}-\mathrm{h}}$ \\
\hline 16 & CKH-08016 & $71.00^{\mathrm{hi}}$ & 184.20 & $79.70^{\mathrm{c}-\mathrm{k}}$ & $14.50^{\mathrm{bc}}$ & 14.40 & 32.80 & 29.35 & $42.23^{\mathrm{c}-\mathrm{h}}$ \\
\hline 17 & CKH-08017 & $76.00^{\mathrm{c}-\mathrm{h}}$ & 184.20 & $77.30^{\mathrm{d}-\mathrm{j}}$ & $14.00^{\mathrm{b}-\mathrm{d}}$ & 14.80 & 33.60 & 28.75 & $30.15^{\mathrm{e}-\mathrm{h}}$ \\
\hline 18 & CKH-08018 & $78.00^{\mathrm{c}-\mathrm{g}}$ & 171.00 & $70.80^{\mathrm{g}-\mathrm{j}}$ & $13.50^{\mathrm{b}-\mathrm{d}}$ & 15.40 & 29.60 & 24.05 & $29.52^{\mathrm{e}-\mathrm{h}}$ \\
\hline 19 & СКH-08019 & $70.00^{\mathrm{i}}$ & 189.30 & $83.80^{\mathrm{b}-\mathrm{i}}$ & $13.00^{\mathrm{b}-\mathrm{e}}$ & 13.60 & 34.10 & 26.65 & $30.76^{\mathrm{c}-\mathrm{h}}$ \\
\hline 20 & CKH-08020 & $80.00^{c-f}$ & 195.60 & $94.80^{\mathrm{b}-\mathrm{e}}$ & $12.50^{\mathrm{b}-\mathrm{e}}$ & 15.20 & 33.80 & 27.05 & $47.83^{\mathrm{b}-\mathrm{g}}$ \\
\hline 21 & CKH-08021 & $77.00^{\mathrm{b}-\mathrm{g}}$ & 192.70 & $79.50^{\mathrm{c}-\mathrm{k}}$ & $14.50^{\mathrm{bc}}$ & 14.00 & 33.80 & 29.30 & $27.77^{\mathrm{c}-\mathrm{h}}$ \\
\hline 22 & CKH-08022 & $81.00^{\mathrm{b}-\mathrm{d}}$ & 187.90 & $79.40^{\mathrm{c}-\mathrm{k}}$ & $12.00^{\mathrm{b}-\mathrm{e}}$ & 15.00 & 32.70 & 26.00 & $31.76^{\mathrm{c}-\mathrm{h}}$ \\
\hline 23 & CKH-08023 & $75.00^{\mathrm{c}-\mathrm{h}}$ & 196.70 & $95.50^{\mathrm{b}-\mathrm{e}}$ & $14.00^{\mathrm{b}-\mathrm{e}}$ & 13.60 & 34.50 & 34.25 & $53.18^{\mathrm{bc}}$ \\
\hline 24 & CKH-08024 & $76.50^{\mathrm{b}-\mathrm{h}}$ & 206.20 & $99.90^{\mathrm{b}}$ & $12.50^{\mathrm{b}}$ & 14.40 & 31.60 & 28.20 & $43.97^{\mathrm{b}-\mathrm{g}}$ \\
\hline 25 & CKH-08025 & $76.50^{\mathrm{b}-\mathrm{h}}$ & 187.80 & $85.60^{\mathrm{b}-\mathrm{i}}$ & $15.00^{\mathrm{b}}$ & 14.60 & 32.30 & 27.50 & $29.39^{\mathrm{e}-\mathrm{h}}$ \\
\hline 26 & CKH-08026 & $76.50^{\mathrm{b}-\mathrm{h}}$ & 196.60 & $89.40^{\mathrm{b}-\mathrm{h}}$ & $11.00^{\mathrm{b}-\mathrm{e}}$ & 14.80 & 29.50 & 23.40 & $33.01^{\mathrm{c}-\mathrm{h}}$ \\
\hline 27 & CKH-08027 & $77.50^{\mathrm{b}-\mathrm{g}}$ & 199.40 & $85.20^{\mathrm{b}-\mathrm{i}}$ & $14.50^{\mathrm{cb}}$ & 14.00 & 34.70 & 29.15 & $37.87^{\mathrm{c}-\mathrm{h}}$ \\
\hline 28 & СКH-08028 & $76.00^{\mathrm{c}-\mathrm{h}}$ & 199.10 & $88.30^{\mathrm{b}-\mathrm{i}}$ & $12.00^{\mathrm{b}-\mathrm{e}}$ & 14.00 & 31.50 & 24.85 & $36.62^{\mathrm{c}-\mathrm{h}}$ \\
\hline 29 & CKH-08029 & $81.50^{\mathrm{a}-\mathrm{c}}$ & 182.60 & $76.20^{\mathrm{d}-\mathrm{j}}$ & $12.50^{\mathrm{b}-\mathrm{e}}$ & 14.40 & 37.70 & 26.65 & $31.89^{c-h}$ \\
\hline 30 & CKH-08030 & $81.00^{\mathrm{b}-\mathrm{d}}$ & 184.70 & $78.60^{\mathrm{d}-\mathrm{j}}$ & $12.50^{\mathrm{b}-\mathrm{e}}$ & 14.60 & 35.40 & 26.15 & $37.87^{\mathrm{c}-\mathrm{h}}$ \\
\hline 31 & CKH-08031 & $77.50^{\mathrm{b}-\mathrm{g}}$ & 186.80 & $81.20^{\mathrm{b}-\mathrm{i}}$ & $10.00^{\mathrm{e}}$ & 14.20 & 34.00 & 27.60 & $47.71^{\mathrm{c}-\mathrm{g}}$ \\
\hline 32 & CKH-08032 & $77.00^{\mathrm{b}-\mathrm{g}}$ & 199.20 & $101.50^{\mathrm{b}}$ & $13.50^{\mathrm{b}-\mathrm{d}}$ & 13.40 & 31.90 & 30.10 & $35.88^{\mathrm{c}-\mathrm{h}}$ \\
\hline 33 & CKH-08033 & $80.50^{\mathrm{b}-\mathrm{d}}$ & 163.60 & $68.30^{\mathrm{h}-\mathrm{j}}$ & $13.50^{\mathrm{b}-\mathrm{d}}$ & 13.60 & 31.90 & 26.30 & $24.79^{\mathrm{gh}}$ \\
\hline 34 & CKH-08034 & $78.50^{\mathrm{b}-\mathrm{g}}$ & 188.00 & $84.00^{\mathrm{b}-\mathrm{i}}$ & $13.00^{\mathrm{b}-\mathrm{e}}$ & 12.80 & 32.30 & 27.85 & $26.41^{f-h}$ \\
\hline 35 & CKH-08035 & $75.50^{\mathrm{c}-\mathrm{h}}$ & 205.80 & $82.10^{\mathrm{b}-\mathrm{i}}$ & $11.50^{\mathrm{c}-\mathrm{e}}$ & 13.60 & 37.40 & 28.00 & $31.39^{c-h}$ \\
\hline 36 & CKH-08036 & $76.50^{\mathrm{b}-\mathrm{h}}$ & 202.60 & $92.50^{\mathrm{b}-\mathrm{f}}$ & $14.50^{\mathrm{cb}}$ & 14.60 & 30.90 & 25.55 & $33.38^{\mathrm{c}-\mathrm{h}}$ \\
\hline 37 & CKH-08037 & $78.00^{\mathrm{b}-\mathrm{g}}$ & 174.80 & $73.50^{f-j}$ & $14.50^{\mathrm{cb}}$ & 14.80 & 29.90 & 23.30 & $27.41^{\mathrm{e}-\mathrm{h}}$ \\
\hline 38 & CKH-08038 & $74.50^{\mathrm{f}-\mathrm{i}}$ & 192.90 & $88.10^{\mathrm{b}-\mathrm{i}}$ & $14.00^{\mathrm{b}-\mathrm{d}}$ & 15.60 & 35.20 & 29.90 & $52.44^{\mathrm{b}-\mathrm{d}}$ \\
\hline 39 & CKH-08039 & $74.50^{\mathrm{f}-\mathrm{i}}$ & 191.50 & $78.20^{\mathrm{b}-\mathrm{j}}$ & $12.50^{\mathrm{b}-\mathrm{e}}$ & 13.80 & 33.40 & 26.75 & $34.384^{\mathrm{c}-\mathrm{h}}$ \\
\hline 40 & СКH-08040 & $73.50^{\mathrm{g}-\mathrm{i}}$ & 203.80 & $95.80^{\mathrm{b}-\mathrm{d}}$ & $13.00^{\mathrm{cb}}$ & 14.20 & 34.10 & 33.00 & $61.54^{\mathrm{b}}$ \\
\hline 41 & QPMHYB1 & $77.00^{\mathrm{b}-\mathrm{g}}$ & 187.30 & $77.90^{\mathrm{d}-\mathrm{j}}$ & $14.00^{\mathrm{b}-\mathrm{d}}$ & 14.00 & 32.30 & 24.95 & $26.03^{f-h}$ \\
\hline 52 & QPMHYB2 & $79.50^{\mathrm{b}-\mathrm{f}}$ & 168.70 & $77.00^{\mathrm{d}-\mathrm{j}}$ & $14.00^{\mathrm{b}-\mathrm{d}}$ & 14.20 & 34.30 & 25.50 & $30.64^{\mathrm{c}-\mathrm{h}}$ \\
\hline 43 & QPMHYB3 & $78.00^{\mathrm{c}-\mathrm{g}}$ & 177.50 & $74.50^{\mathrm{e}-\mathrm{j}}$ & $14.00^{\mathrm{b}-\mathrm{d}}$ & 14.40 & 30.30 & 28.90 & $24.54^{\mathrm{gh}}$ \\
\hline 44 & WH403 & $77.50^{\mathrm{b}-\mathrm{g}}$ & 188.20 & $83.90^{\mathrm{b}-\mathrm{i}}$ & $13.00^{\mathrm{b}-\mathrm{e}}$ & 14.40 & 34.70 & 28.45 & $42.10^{\mathrm{b}-\mathrm{h}}$ \\
\hline 45 & BH-660 & $86.50^{\mathrm{a}}$ & 261.40 & $147.20^{\mathrm{a}}$ & $24.00^{\mathrm{a}}$ & - & - & 42.90 & $106.76^{\mathrm{a}}$ \\
\hline \multicolumn{2}{|c|}{ Mean } & 77.37 & 189.67 & 84.17 & 13.52 & 14.31 & 37.7 & 27.64 & 36.48 \\
\hline \multicolumn{2}{|c|}{ CV (\%) } & 3.07 & 8.62 & 10.28 & 12.16 & 6.78 & 9.70 & 13.67 & 30.26 \\
\hline \multicolumn{2}{|c|}{ LSD (0.05) } & 2.05 & NS & 17.72 & 3.37 & NS & NS & NS & 22.61 \\
\hline
\end{tabular}

NS: nonsignificant; TS: days to 50\% tasseling; PH: plant height; EH: ear height; PC: plant count; NRE: number of kernel-rows per ear; NKR: number of kernels per row; HGWt: hundred-grain weight. Means in the same column with the same letter are not statistically different at $p \leq 0.05$.

$$
\begin{aligned}
& r_{p}=\frac{p \operatorname{cov} x \cdot y}{\sqrt{\delta^{2} p x \cdot \delta^{2} p y}} \\
& r_{g}=\frac{g \operatorname{cov} x \cdot y}{\sqrt{\delta^{2} g x \cdot \delta^{2} g y}}
\end{aligned}
$$

where $r_{p}$ and $r_{g}$ are phenotypic and genotypic correlation coefficients, respectively; $p \operatorname{cov} x \cdot y$ and $g \operatorname{cov} x \cdot y$ are phenotypic and genotypic covariances between variables $x$ and $y$, respectively; $\delta^{2} p x$ and $\delta^{2} g x$ are phenotypic and genotypic variances, respectively, for variable $x$; and $\delta^{2} p y$ and $\delta^{2} g y$ are phenotypic and genotypic variances, respectively, for variable $y$. 
2.5. Path Coefficient Analysis. Path coefficient analysis was computed as suggested by Dewey and Lu [15] by using genotypic correlation coefficients as

$$
r_{i j}=P_{i j}+\sum r_{r k} P_{k j}
$$

where $r_{i j}$ denotes the mutual association between the independent character $i$ (yield-related trait) and dependent character $j$ (grain yield) as measured by the genotypic correlation coefficients; $P_{i j}$ refers to the components of direct effects of the independent character $i$ on the dependent character $j$ as measured by the path coefficients; and $\sum r_{i k} P_{k j}$ refers to the summation of components of indirect effects of a given independent character $i$ on a given dependent character $j$ via all other independent characters $k$. The contribution of the remaining unknown characters is measured as the residual as given by

$$
P_{R}=\sqrt{\left(1-\sum P_{i j} r_{i j}\right)}
$$

\section{Results and Discussion}

3.1. Phenotypic and Genotypic Correlations. Phenotypic and genotypic correlations among the traits considered in the study are presented in Table 3 . In the following, the implications of the data generated by the analyses are provided.

3.2. Phenotypic Correlation. Study of the values of the phenotypic correlation coefficients indicated in Table 3 below the diagonal line shows that grain yield per hectare gave a positive phenotypic correlation with all traits except days to $50 \%$ tasseling and plant count. Grain yield has the highest statistically significant correlations with plant height ( $r p=0.697 ; p \leq 0.01)$ followed by number of kernels per row $(r p=0.626 ; p \leq 0.01)$, ear height $(r p=0.440 ; p \leq 0.05)$, and 100 -grain weight $(r p=0.436 ; p \leq 0.05)$. Some researchers reported similar observations, e.g., $[11,16-22]$. The researchers observed that plant height, ear aspect, ear height, ear length, grains per row, and 100-grain weight or grain yield were positively and significantly inter-correlated implying that hybrids with these traits possess high yield potential.

The highest positive phenotypic correlation was observed between plant height and ear height $(r p=0.788 ; p \leq 0.01)$. Similar observation was reported by several researchers [19-23]. These observations indicate that improvements in each of the traits would lead to overall improvements of the genotypes. Such correlations help in making reasonable decisions in selecting traits controlled by multiple genes. Grain yield, as a quantitative trait, is polygenically controlled [24]. These findings imply that effective yield improvement depends on simultaneous improvements in all yield components. In fact, selection efforts based on grain yield alone are often less effective and efficient [9]. Selections need to be made based on various traits of the crop at hand.

3.3. Genotypic Correlation. Observation of genotypic correlation coefficients shows that all traits examined in our study have a positive correlation with yield per hectare except plant count and number of kernel-rows per ear (Table 3). Traits that showed high genotypic correlations with grain yield per hectare are plant height $(r g=0.873$; $p \leq 0.01)$, ear height $(r g=0.698 ; p \leq 0.01)$, days to $50 \%$ tasseling $(r g=0.585 ; p \leq 0.01)$, and 100-grain weight $(r g=0.506 ; p \leq 0.01)$. Similar findings were reported elsewhere $[9,24,25]$. On the contrary, significant and negative genotypic correlation was observed between yield per hectare and number of kernel-rows per ear $(r g=0.744$; $p \leq 0.01)$. This finding is contrary to the findings of some researchers [26, 27]. The fact that the higher number of kernel-rows per ear does not correlate with yield may imply that the kernels are smaller and lighter. It is helpful to note that the number of rows per ear and the number of grains per row of the local check were not studied.

In general, genotypic correlations among traits affecting grain yield explain true association as they exclude the environmental influences. It can be suggested that improvements in grain yield of maize can be accomplished through selections based on these correlations. Hence, knowledge of associations between yield and its component traits as well as among the component traits themselves can promote the efficiency of selection in maize breeding programs. In fact, it is well established that correlation studies between yield and yield components are pre-requisite in planning effective breeding programs. The same is true with maize breeders [27]. Quantitative traits like grain yield express themselves in close association with many other traits. Change in the expression of one trait is usually associated with changes in the expression of many other traits. Therefore, the correlations obtained in the present study are useful in the selection of traits having direct and significant correlation in improving grain yield.

3.4. Path Coefficient Analyses. Results of path coefficient analysis of all other traits to grain yield per hectare are given in Table 4 and Figure 1. The results of path coefficient analysis revealed that all the characters studied except plant height, plant count, and number of kernel-rows per ear had positive direct effects on grain yield. The highest direct positive effect on yield per hectare was exhibited by ear height (0.6514). This implies that higher ear height leads to increased grain yield; the genotypic correlation between ear height and grain yield $(r g=0.698 ; p \leq 0.01)$ is predominately attributed to the direct effect $(r g=0.651 ; p \leq 0.01)$ of ear height on the grain yield per hectare (Figure 1). Many research findings were in line with this finding [12, 28, 29]. Similarly, it is also in agreement with the findings of Asrarur-Rehman et al. [23] and Bello et al. [24]. These researchers reported positive and significant direct effects of ear length and thousand-kernel weight on grain yield. However, the finding of the present study contradicts with the findings of Rafiq et al. [25].

Days to $50 \%$ tasseling has yielded the next highest and direct effect on grain yield (0.245). It is stated above that the genotypic correlation between the traits is positive and statistically significant $(r g=0.585 ; p \leq 0.01)$. The correlation explains the true relationship between the two traits; thus, 
TABLE 3: Genotypic and phenotypic correlation coefficients among the traits.

\begin{tabular}{lcccccccc}
\hline Traits & TS & PH & EH & PC & NRE & NKR & HGWt & Yield \\
\hline TS & - & -0.490 & -0.176 & -0.120 & -0.204 & -0.347 & $0.334^{*}$ & $0.585^{* *}$ \\
PH & -0.274 & - & $0.579^{* *}$ & $0.412^{*}$ & -0.218 & $0.374^{*}$ & 0.205 \\
EH & -0.331 & $0.786^{* *}$ & - & -0.094 & 0.286 & $-0.079^{*}$ & -0.140 \\
PC & -0.130 & -0.164 & -0.031 & - & $0.683^{* *}$ & 0.321 & $0.789^{* *}$ \\
NRE & -0.140 & 0.146 & -0.074 & $-0.483^{*}$ & - & -0.698 & $-0.613^{* *}$ & $0.698^{* *}$ \\
NKR & -0.151 & $0.546^{* *}$ & $0.481^{*}$ & -0.088 & $0.405^{*}$ & $-0.744^{* *}$ \\
HGWt & -0.363 & 0.162 & 0.210 & 0.166 & -0.085 & 0.280 & $0.719^{* *}$ & -0.233 \\
Yield & -0.244 & $0.697^{* *}$ & $0.448^{*}$ & -0.040 & 0.323 & $0.626^{* *}$ & $0.626^{* *}$ & $0.506^{* *}$ \\
\hline
\end{tabular}

* Statistically significant correlation at $p \leq 0.05 ;{ }^{* *}$ statistically significant correlation at $p \leq 0.01$; TS: days to $50 \%$ tasseling; PH: plant height; EH: ear height; PC: plant count; NRE: number of kernel-rows per ear; NKR: number of kernels per row; HGWt: hundred-grain weight.

TABLE 4: Direct (boldface) and indirect effects of different traits on grain yield.

\begin{tabular}{lcccccccc}
\hline Traits & TS & PH & EH & PC & NRE & NKR & HGWt \\
\hline TS & $\mathbf{- 0 . 0 2 3}$ & -0.013 & 0.074 & 0.330 & 0.262 & 0.113 & 0.161 \\
PH & 0.099 & $-\mathbf{0 . 2 1 3}$ & 0.930 & 0.530 & 0.396 & 0.506 & 0594 \\
EH & 0.070 & -0.372 & $\mathbf{0 . 7 0 0}$ & 0.570 & 0.099 & -0.217 & 0.095 \\
PC & 0.212 & -0.367 & 0.618 & $-\mathbf{0 . 0 4 1}$ & 0.110 & -0.230 & $0.095^{* *}$ \\
NRE & -0.208 & 0.308 & -0.526 & 0.183 & $\mathbf{0 . 2 0 5}$ & 0.222 & -0.099 & $-0.693^{* *}$ \\
NKR & -0.159 & 0.306 & -0.580 & 0.192 & -0.111 & $\mathbf{0 . 1 7 6}$ & -0.078 & $-0.744^{* *}$ \\
HGWt & 0.055 & -0.104 & 0.453 & -0.117 & 0.120 & -0.057 & 0.233 \\
\hline
\end{tabular}

Residual: 0.204; TS: days to 50\% tasseling; PH: plant height; EH: ear height; PC: plant count; NRE: number of kernel-rows per ear; NKR: number of kernels per row; HGWt: hundred-grain weight.

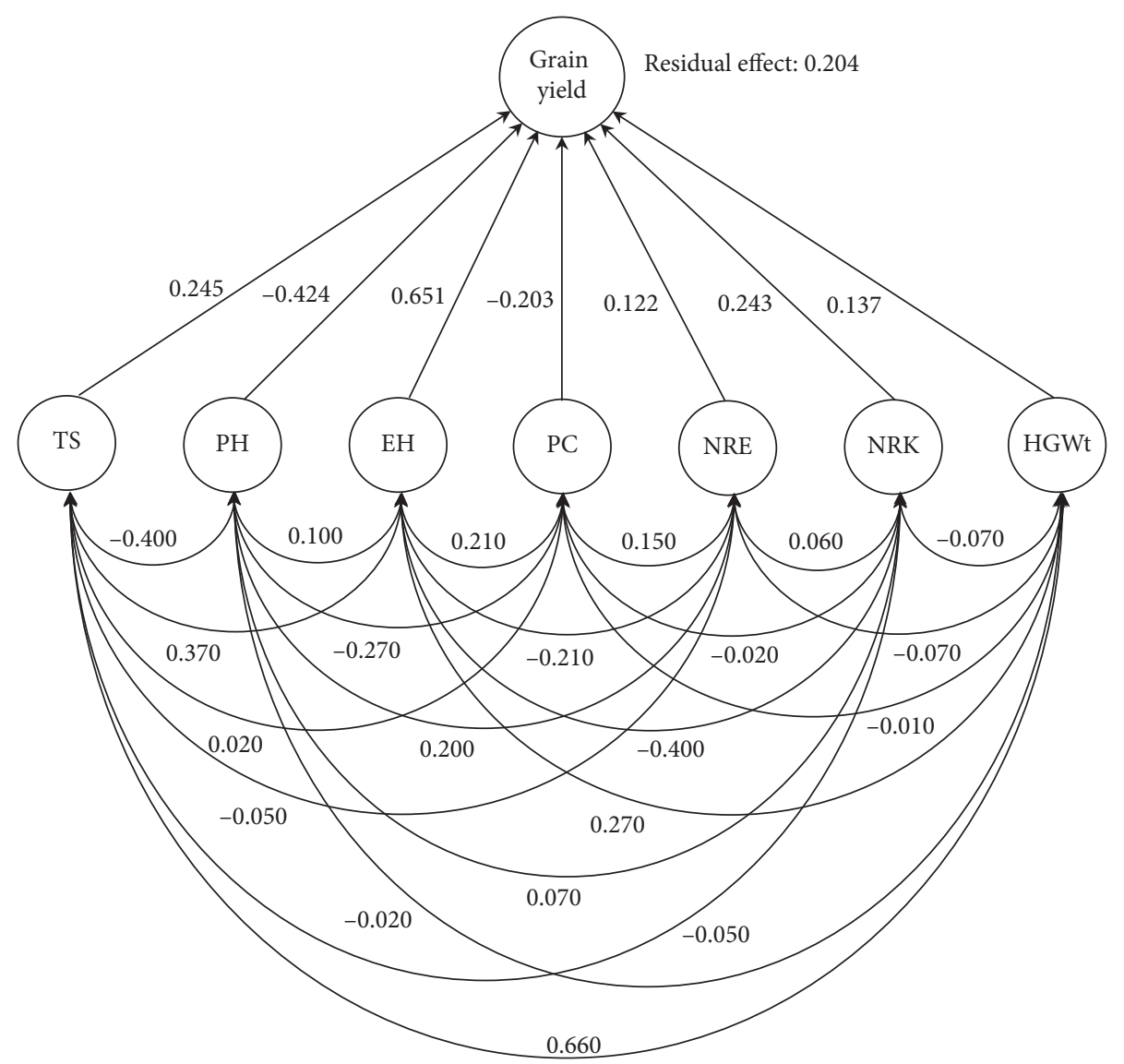

FIGURE 1: Average genotypic path coefficient diagram representing cause and effect relationships among quantitative traits and grain yield (TS: days to 50\% tasseling; PH: plant height; EH: ear height; PC: plant count; NRE: number of kernel-rows per ear; NKR: number of kernels per row; HGWt: hundred-grain weight). 
selection based on days to $50 \%$ tasseling would be effective. This is in contrast with the findings of Arsode et al. [28] who reported significant negative association of days to $50 \%$ tasseling with grain yield per plant and plant height, ear length, ear girth, number of kernel-rows per ear, and number of kernels per row.

Plant count showed negative direct effect on grain yield $(-0.041)$ like its genotypic correlation with grain yield $(-0.242)$, implying that there is true association of the two traits. However, plant count yielded high positive indirect effect on grain yield through ear height (0.570). Likewise, number of kernel-rows per ear and number of kernels per row showed higher positive indirect effect on grain yield through plant height. These results are in line with the reports of different authors $[10-12,30]$. The negative and significant genotypic correlation between number of kernel-rows per ear and grain yield $(r g=-0.744 ; p \leq 0.01)$ explains the true relationship of the traits. Plant height resulted in high and negative direct effect on grain yield $(-0.424)$. Other researchers have reported similar findings $[25,32]$. However, we observed highest and significant genotypic correlation between plant height and grain yield $(r g=0.873 ; p \leq 0.01)$. This may be due to the indirect effect of plant height on ear height. Thus, we recommend that selection based on plant height is made cautiously. We also observed that 100 -grain weight had positive and significant direct effect on the grain yield as indicated in Table 4 (0.338; $r g=0.506 ; p \leq 0.01)$. Other studies reported similar results $[33,34]$. The correlations and intercorrelations show that the seven causal traits (i.e., the causal variables) explain much of the variability in grain yield. In fact, a residual effect of 0.204 (Figure 1) implies that the causal traits explained about $79.6 \%$ of the variability in the grain yield, leaving $20.4 \%$ of the variability unexplained.

\section{Concluding Remarks}

Genotypic correlation coefficients showed that all the traits considered in our study have positive correlation with yield per hectare except plant count and number of kernel-rows per ear. Plant height, ear height, days to $50 \%$ tasseling, and 100 -grain weight showed high genotypic correlations with grain yield per hectare. Genotypic correlations among traits affecting grain yield explain the true association as they exclude any environmental influences. Hence, it can be concluded that plant height, ear height, days to $50 \%$ tasseling, and 100-grain weight are the best traits for selection to improve grain yield per hectare of the maize genotypes tested in our study.

\section{Data Availability}

Data used in preparing this manuscript is available from the corresponding author on reasonable request.

\section{Conflicts of Interest}

The authors declare that they have no conflicts of interest.

\section{Acknowledgments}

The authors acknowledge the Rural Capacity Building Project of Oromia State of Ethiopia for funding the research.

\section{References}

[1] B. M. Prasanna, S. K. Vasal, B. Kassahun, and N. N. Singh, "Quality protein maize. Review article," Current Science, vol. 81, no. 10, pp. 1308-1319, 2001.

[2] S. K. Vasal, "Quality protein maize: overcoming the hurdles," in Food Systems for Improved Human Nutrition: Linking Agriculture, Nutrition, and Productivity, P. K. Kataki and S. C. Babu, Eds., pp. 193-227, Food Products Press: an Imprint of the Haworth Press, Inc., Philadelphia, PA, USA, 2002.

[3] B. C. Gibbon and B. A. Larkins, "Molecular genetic approaches to developing quality protein maize," Trends in Genetics, vol. 21, no. 4, pp. 227-233, 2005.

[4] M. D. Ignjatovic, G. Stankovic, K. Markovic, V. Lazic-Jancic, and M. Denic, "Quality protein maize (QPM)," Genetika, vol. 40, no. 30, pp. 205-214, 2008.

[5] K. Dreher, M. Morris, M. Khairallah, J. M. Ribaut, S. Pandey, and G. Srinivasan, "Is marker-assisted selection cost-effective compared to conventional plant breeding methods? The case of quality protein maize," in Proceedings of the 4th Annual Conference of the International Consortium on Agricultural Biotech Research: the Economics of Agricultural Biotechnology, Ravello, Italy, August 2000.

[6] M. Bjarnason and S. K. Vasal, "Breeding of quality protein maize," Plant Breeding Review, vol. 9, pp. 181-216, 1992.

[7] S. K. Vasal, E. Villegas, C. Y. Tang, J. Werder, and M. Read, "Combined use of two genetic systems in the development and improvement of quality protein maize," Kulturpflanze, vol. 32, pp. 171-185, 1984.

[8] N. Belay, "Genetic variability, heritability, correlation and path coefficient analysis for grain yield and yield component in maize (Zea mays L.) hybrids," Advances in Crop Science and Technology, vol. 6, p. 399, 2018.

[9] S. A. Mohammadi, B. M. Prasanna, and N. N. Singh, "Sequential path model for determining interrelationships among grain yield and related characters in maize," Crop Science, vol. 43, no. 5, pp. 1690-1697, 2003.

[10] J. Tadesse and T. Leta, "Association and path coefficient analysis among grain yield and related traits in Ethiopian maize (Zea mays L.) inbred lines," African Journal of Plant Science, vol. 13, no. 9, pp. 264-272, 2019.

[11] M. K. Shengu, "Path coefficient analysis of early maturing maize (Zea mays) inbred lines in central rift valley of Ethiopia," Plant, vol. 5, no. 3, pp. 47-50, 2017.

[12] M. Muneeb, S. Muhammad, H. Ghazanfar, and M. Yasir, "Correlation and path analysis of grain yield components in exotic maize (Zea mays L.) hybrids," International Journal of Sciences: Basic and Applied Research (IJSBAR), vol. 12, no. 1, pp. 22-27, 2013.

[13] BPEDORS [Bureau of Planning and Economic Development of Oromia Regional State], Physical and Socioeconomic Profile of 180 Districts of Oromia Region, Oromia State Physical Planning Development, Finfinne, Ethiopia, 2000.

[14] R. K. Singh and B. D. Chaudhry, Biometrical Methods in Quantitative Genetic Analysis, Kalyani Publishers, New Delhi, India, 1985.

[15] D. R. Dewey and K. H. Lu, "A correlation and path-coefficient analysis of components of crested wheatgrass seed production," Agronomy Journal, vol. 51, no. 9, pp. 515-518, 1959. 
[16] A. Izzam, H. Rehman, A. Sohail, S. Ali, H. Manzoor, and Q. Hussain, "Genetic variability and correlation studies for morphological and yield traits in maize (Zea mays L.)," Pure and Applied Biology, vol. 6, no. 4, 2017.

[17] G. Singh, R. Kumar, and Jasmine, "Genetic parameters and character association study for yield traits in maize (Zea mays L.)," Journal of Pharmacognosy and Phytochemistry, vol. 6, no. 5, pp. 808-813, 2017.

[18] G. B. Adu, R. Akromah, M. S. Abdulai, R. Akromah et al., "Trait association for improved grain yield of extra-early maturing maize hybrids evaluated in the forest and transitional zones of Ghana," Australian Journal of Crop Science, vol. 10, no. 8, pp. 1127-1135, 2016.

[19] M. Filipovic, M. Babic, N. Delic, G. Bekavac, and V. Babic, "Determination relevant breeding criteria by the path and factor analysis in maize," Genetika, vol. 46, no. 1, pp. 49-58, 2014.

[20] M. A. B. Fakorede, A. Oluwaranti, B. Badu-Apraku, and A. Menkir, "Trait association of maize varieties in contrasting seasons in the rainforest of southwest Nigeria," African Crop Science Conference Proceedings, vol. 10, pp. 541-544, 2011.

[21] S. K. Khavari Khorasani, M. Kh, E. Zandipour, and A. Heidarian, "Multivariate analysis of agronomic traits of new corn hybrids (Zea mays L.)," International Journal of AgriScience, vol. 1, no. 6, pp. 314-322, 2011.

[22] B. M. Ashofteh, B. A. SiahSar, S. Khavari, M. Golbashy, N. N. Nejad, and A. Alizade, "Effects of genotype by environment interactions on morphological traits, yield and yield components of new grain corn (Zea mays L.) varieties," Agroecology, vol. 2, no. 1, pp. 151-161, 2010.

[23] S. Asrar-ur-Rehman, U. Saleem, and G. M. Subhani, "Correlation and path coefficient analysis in maize (Zea mays L.)," Journal of Agricultural Science, vol. 45, no. 3, pp. 177-183, 2007.

[24] O. B. Bello, S. Y. Abdulmaliq, M. S. Afolabi, and S. A. Ige, "Correlation and path coefficient analysis of yield and agronomic characters among open pollinated maize varieties and their $\mathrm{F}_{1}$ hybrids in a diallel cross," African Journal of Biotechnology, vol. 9, no. 18, pp. 2633-2639, 2010.

[25] C. M. Rafiq, M. Rafique, A. Hussain, and M. Altaf, "Studies on heritability, correlation and path analysis in maize (Zea mays L.)," Journal of Agricultural Research, vol. 48, no. 1, pp. 35-38, 2010.

[26] S. E. Sadek, M. A. Ahmed, and H. M. Abd El-Ghaney, "Correlation and path coefficient analysis in five parents inbred lines and their six white maize (Zea mays L.) single crosses developed and grown in Egypt," Journal of Applied Science Research, vol. 2, no. 3, pp. 159-167, 2006.

[27] A. A. Wannows, H. K. Azzam, and S. A. Al-Ahmad, "Genetic variances, heritability, correlation and path coefficient analysis in yellow maize crosses (Zea mays L.)," Agriculture and Biology Journal of North America, vol. 1, no. 4, pp. 630-637, 2010.

[28] P. Arsode, M. Krishna, N. Sunil, and S. Vani Sree, "Correlation studies for grain yield and its components in hybrids of quality protein maize (Zea mays 1.)," The Journal of Research PJTSAU, vol. 46, no. 2-3, pp. 85-88, 2018.

[29] R. Kumar, R. B. Dubey, K. D. Ameta, R. Kunwar, R. Verma, and P. Bisen, "Correlation and path coefficient analysis for yield contributing and quality traits in quality protein maize (Zea mays L.)," International Journal of Current Microbiology and Applied Sciences, vol. 6, no. 10, pp. 2139-2146, 2017.

[30] H. Kinfe, G. Alemayehu, L. Wolde, and Y. Tsehaye, "Correlation and path coefficient analysis of grain yield and yield related traits in maize (Zea mays L.) hybrids, at Bako, Ethiopia," Journal of Biology, Agriculture and Healthcare, vol. 5, no. 15, pp. 44-53, 2015.

[31] D. O. Olawamide and L. S. Fayeun, "Correlation and path coefficient analysis for yield and yield components in late maturing pro-vitamin A synthetic maize (Zea mays L.) breeding lines," Journal of Experimental Agriculture International, vol. 42, no. 1, pp. 64-72, 2020.

[32] D. K. Parh, M. A. Hossain, and M. J. Uddin, "Correlation and path coefficient analysis in open pollinated maize (Zea mays L.)," Bangladesh Journal of Agriculture, vol. 11, pp. 11-14, 1986.

[33] G. Beulah, S. Marker, and D. Rajasekhar, "Assessment of quantitative genetic variability and character association in maize (Zea mays L.)," Journal of Pharmacogency and Phytochemistry, vol. 7, no. 1, pp. 2813-2816, 2017.

[34] D. S. Jakhar, R. Singh, and A. Kumar, "Studies on path coefficient analysis in maize (Zea mays L.) for grain yield and its attributes," International Journal of Current Microbiology and Applied Science, vol. 6, no. 4, pp. 2851-2856, 2017. 